\title{
WestVirginiaUniversity
}

THE RESEARCH REPOSITORY @ WVU

Graduate Theses, Dissertations, and Problem Reports

2020

\section{The Effect of Newspaper Closure on Local Media Ecology}

Cody David Nespor

West Virginia University, cdn0004@mix.wvu.edu

Follow this and additional works at: https://researchrepository.wvu.edu/etd

Part of the Journalism Studies Commons

\section{Recommended Citation}

Nespor, Cody David, "The Effect of Newspaper Closure on Local Media Ecology" (2020). Graduate Theses, Dissertations, and Problem Reports. 7557.

https://researchrepository.wvu.edu/etd/7557

This Thesis is protected by copyright and/or related rights. It has been brought to you by the The Research Repository @ WVU with permission from the rights-holder(s). You are free to use this Thesis in any way that is permitted by the copyright and related rights legislation that applies to your use. For other uses you must obtain permission from the rights-holder(s) directly, unless additional rights are indicated by a Creative Commons license in the record and/ or on the work itself. This Thesis has been accepted for inclusion in WVU Graduate Theses, Dissertations, and Problem Reports collection by an authorized administrator of The Research Repository @ WVU. For more information, please contact researchrepository@mail.wvu.edu. 
The Effect of Newspaper Closure on Local Media Ecology

\author{
Cody D. Nespor
}

Thesis submitted

to the Reed College of Media

at West Virginia University

in partial fulfillment of the requirements for the degree of

Master of Science in

Journalism

Bob Britten, Ph.D., Chair

John Temple, Ph.D.

Adell Crow

Thomas Stewart

Reed College of Media

Morgantown, West Virginia

2020

Keywords: Journalism, Newspaper, Local, Print, Broadcast, Closure, Hyperlocal, New Media Copyright 2020 Cody Nespor 


\begin{abstract}
The Effect of Newspaper Closure on Local Media Ecology
\end{abstract}

\title{
Cody D. Nespor
}

On August 31, 2019, the local newspaper of Youngstown, Ohio, The Vindicator, ceased publication after 150 years. The Vindicator's closure left Youngstown as the largest city in the United State without a major newspaper. As local newspaper closures become more and more common across communities, there are questions on how, and if, the coverage and content those newspaper provide to their communities can be replaced or will simply be lost forever. This study has three research questions. Question one pertains to the amount of original reporting that will exist without The Vindicator. Questions two asks about the amount of locally focused content that will be produced without The Vindicator. Question three asks how news outlets that continue to publish following The Vindicator's closure will fulfil the community's critical information needs (CIN). To answer these questions, a content analysis was conducted comparing a constructed week from the final six months of The Vindicator's existence compared to a week-long sample of five news outlets that continue to publish in the Youngstown area following The Vindicator's closing. Content from all six publications were coded for original reporting, local focus and fulfilling the community's critical information needs. The results from this content analysis show that, by themselves, none of the examined outlets would be able to replace The Vindicator on their own. However, when viewing all five outlets together, there still exists a robust local media ecology in Youngstown following The Vindicator's closing. 


\section{Table of Contents}

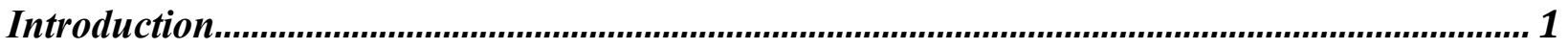

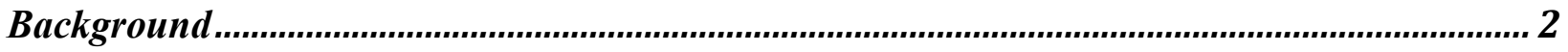

The Importance of Having a Local Newspaper......................................................................... 3

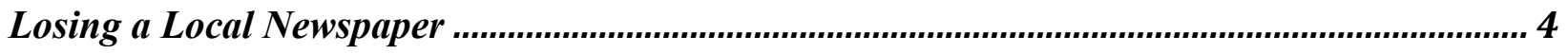

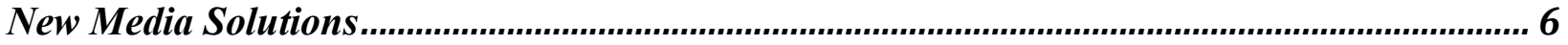

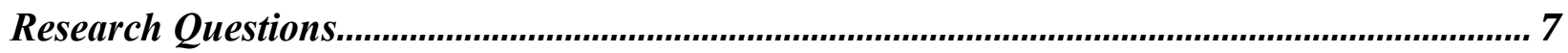

Methodology

The Framework for Measurement …...................................................................................

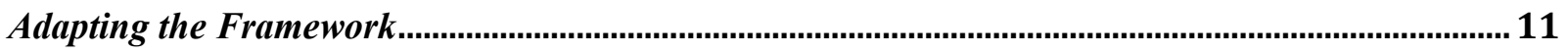

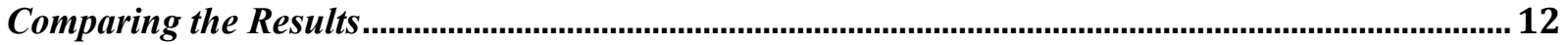

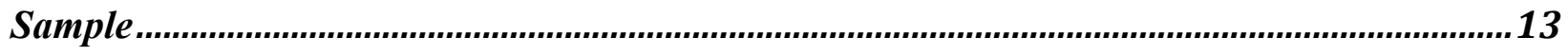

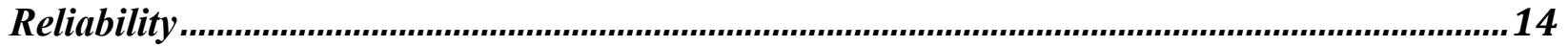

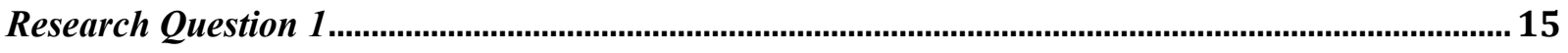

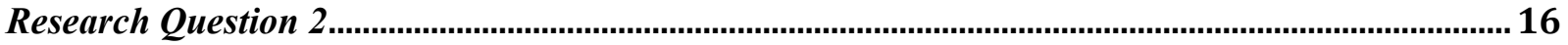

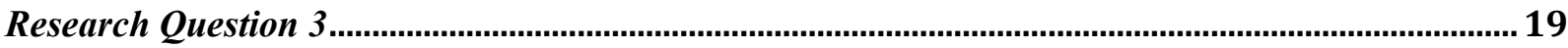

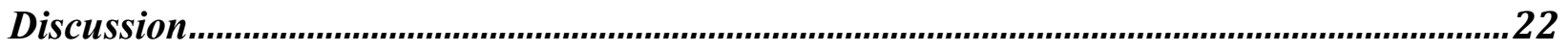

Limitations...,

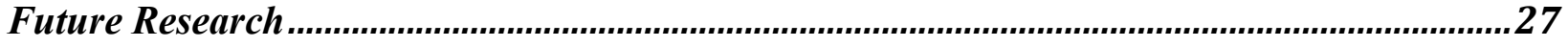

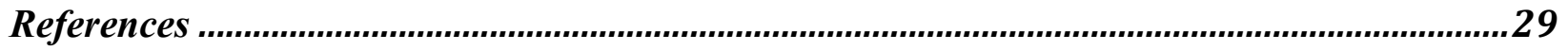

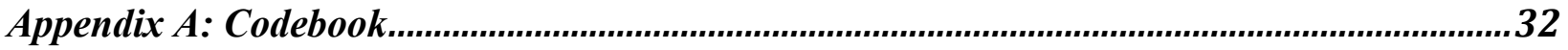




\section{Introduction}

On June 22, 2019, The Vindicator, the daily newspaper of Youngstown, Ohio, celebrated its 150th anniversary. The Vindicator ceased production 71 days later on August 31, leaving Youngstown as the largest city in the United States without a major newspaper (Gabbatt, 2019). The Vindicator had the same problems that most of America's print industry is plagued with: declining revenue from advertisements and a diminished subscriber base (Nelson, 2019).

Without The Vindicator there are still news outlets in Youngstown producing local content. There are also a few outlets that have moved into the Mahoning Valley area specifically to try and replace The Vindicator's content. Previous research has examined how and why newspapers fail as well as how newspaper closures affect communities, but little has been done in the way of examining whether or not a community's information needs can be met after losing its newspaper. (Wadbring and Bergstrom, 2017; Smethers et al, 2007).

Napoli, et al (2017) proposed a model for measuring how well a local journalism ecosystem can fulfil the information needs of its community. Using the ideas presented with this model, this study will attempt to determine to what extent the information needs of the Youngstown and Mahoning Valley communities can be fulfilled by the post-Vindicator local media ecosystem. This will be done by tracking a week's worth of content produced by several existing news outlets in the area and comparing the results to a constructed week's worth of content produced by The Vindicator prior to its closing. The content will also be coded for originality, locality, and how it addresses the community's critical information needs. 


\section{Background}

The Vindicator's absence has created a news void in the Mahoning Valley. The county seat of Mahoning County, Youngstown was the ninth largest city in Ohio as of the 2010 census with a population of 65,062 (U.S. Census Bureau, 2018). The Vindicator was the only newspaper that carried complete coverage of Mahoning, Trumbull and Columbiana counties; the nearby Tribune Chronicle focused coverage on the Warren area.

Several entities, however, have already mobilized to try and fill that void. Ogden Newspapers Inc., owners of The Tribune Chronicle, finalized a deal with The Vindicator Publishing Company to acquire The Vindicator's name, masthead, domain name, and subscriber list (Benton, 2019). The Tribune Chronicle now produces a Mahoning Valley section of the paper that is distributed to former Vindicator subscribers under the name "The Vindicator". The Tribune Chronicle has several reporters dedicated exclusively to covering The Vindicator's former coverage area.

Youngstown's media void has also attracted some national attention. Google and McClatchy Publishing had teamed up in March 2019 and announced the beginning of the Compass Experiment (Froman, 2019). Their experiment is meant to test new approaches in local news business models. They planned to start local news outlets in three cities that lack such coverage over the next three years.

After The Vindicator's closing, it was announced that the Compass Experiment's first location would be Youngstown with the Mahoning Matters news website (Jenkins, 2019a). Mahoning 
Matters is being led by Mandy Jenkins, who has already hired several former Vindicator reporters to work for the website (Jenkins, 2019b).

Finally, Youngstown is home to several television news stations with network affiliations; WFMJ (NBC) and WKBN (CBS). Other legacy media in Youngstown, media prevalent prior to the information age such as print and broadcast, have already begun to hire former Vindicator reporters in an attempt to bolster their local coverage (Boney, 2019).

\section{The Importance of Having a Local Newspaper}

Local newspapers play vital roles in their communities beyond just providing news. Newspaper readership is the best predictor of political involvement and community identification (Jeffres et al, 2002). Barnett and Townend (2015) assert that local newspapers fulfill four roles in their communities' democratic and civil life: informing, representing, campaigning, and interrogation.

Informing a community empowers citizens to understand and engage in their communities. Newspapers' coverage of issues directly affects how the public evaluates government services (Jeffres et al, 2002). Representing deals with how the newspaper expresses popular opinion. This representation creates information flow in the opposite direction, where the public informs those in power. Campaigning is the proactive version of representation, where the newspaper promotes and gathers support for the changes suggested by citizens. Interrogation is the newspaper's watchdog role, holding those in power accountable (Barnett and Townend, 2015). 
Community newspaper readership has also been tied to community integration, attachment and involvement (Watson and Cavanah, 2015). Higher local media use leads to higher community attachment and, in turn, higher community attachment leads to higher local media use (Hoffman and Eveland, 2010).

Smith (2008) argued that reporters connecting with their community is what makes community newspapers important. Through their connection with the community, local reporters have the ability to write with the community's point of view in mind. Kenneth Byerly (as cited in Smith, 2008) made this distinction: "community newspapers have something that city dailies lack nearness to people (p. 108).”

A newspaper provides its community value beyond just reporting the news that other outlets do not. Even if remaining outlets can replace the content of a newspaper, the community involvement and integration aspects of reading a community newspaper may still be lost.

\section{Losing a Local Newspaper}

Without their own local newspaper, Mahoning Valley residents will have to rely on other outlets and other media to replace the value that The Vindicator provided, and it has yet to be seen if that is possible. When a newspaper closes entirely, the four roles (informing, representing, campaigning, and interrogation) identified by Jeffres et al (2002) are left entirely unfulfilled, and the community members suffer. Although other media outlets exist in these areas, replacing an entire newspaper is difficult to accomplish. 
Smethers et al (2007) studied the case of the Humboldt Union, a community newspaper in Humboldt, Kansas that closed in 2005 after 129 years of publishing. They found that more than 90 percent of the former subscribers they surveyed both felt that every community needs a newspaper and that they missed having one in their community. After The Union closed a nearby newspaper, The Iola Register, began printing a Humbodlt section, much like the Tribune Chronicle is doing in Youngstown and 60 percent of those surveyed felt that this area newspaper did not provide adequate coverage to their community and 94 percent of participants thought that local radio and TV stations did not fill the information void left by the newspaper. Even though another newspaper started covering Humboldt and other local media was present, residents still missed the content The Union used to provide. Outside of other legacy media, independent and new media organizations have also been found to fail to produce enough content to replace that of a newspaper (Siles and Boczkowski 2012; Nygren et al 2017).

Beyond just the content of a local newspaper, the value of reading a community newspaper is also difficult to replicate. Shaker (2014) studied the closures of the Rocky Mountain News in Denver, Colorado and Seattle Post-Intelligencer in Seattle, Washington and found that newspaper closure directly relates to lower civic engagement. Shaker compared citizens of Denver's and Seattle's responses to the U.S. Census Bureau's Current Population Survey (CPS) from years before and after each newspaper closed. Shaker found that activities such as contacting public officials, joining neighborhood groups, and participating in civic organizations all decreased following the newspapers' closures. 
Shaker (2014) dismissed the idea that the news itself, not the newspaper, is what is important to the community, because he found that after the closure of the two papers, civic engagement in both Denver and Seattle declined at a faster rate than the national average even though alternative news outlets exist in both cities. Shaker asserted that newspapers still provide their communities with value that cannot yet be given through digital media, at least for now. These studies show that both the extrinsic and intrinsic values of a newspaper are difficult to replace regardless of situation or location.

\section{New Media Solutions}

All-digital outlets have begun appearing in recent years in an attempt to fill the gaps left by the decline of legacy media (Metzgar et al 2011). These outlets, dubbed hyperlocals, aim to provide information to smaller communities that are left behind when legacy media fails. Metzgar et al (2011) defined hyperlocals as "geographically-based, community-oriented, original-newsreporting organizations indigenous to the web and intended to fill perceived gaps in coverage of an issue or region and to promote civic engagement" (p. 774). These outlets produce content specifically for the area they cover and nothing more. The idea being that the local audience will be attracted by local news that is not available elsewhere. However, hyperlocals struggle to both produce enough content to replace a newspaper and, at times, generate enough revenue to remain operable.

In general, hyperlocals have yet to be wholly successful in replicating traditional newspapers. Nygren et al (2017) point out that legacy media produce important local content and maintain an editorial presence in their communities that is difficult for hyperlocals to replicate. They found 
that hyperlocals produced less local content, less frequently than even declining legacy media generally can. This disparity in content presents challenges for hyperlocals to find success in replacing legacy media (Nygren et al 2017) or financially (Barnett and Townend 2015).

The financial failing of hyperlocals is not a problem of perception. On the whole, online news is not viewed as an inferior product to print news (Ha and Zhang 2017), even though print news is viewed as more credible and accurate. The issue is that young people are used to obtaining information on the internet for free, so there is a small potential subscriber base for hyperlocals to draw from (Wadbring and Bergstrom 2017). Online content is also often briefer and simpler than news in print, making people less willing to pay for it.

\section{Research Questions}

Past research has found that area newspapers, local television news (Smethers et al, 2007), and new media (Nygren et al, 2017) fail to produce enough local content to replace that which a local newspaper produces. However, that research examined outlets' ability to replace a newspaper through qualitative means such as surveying a newspaper's former subscribers or community leaders. This study will take a quantitative approach. By examining the actual content produced by the news outlets serving Youngstown after The Vindicator's closure and comparing the results against what The Vindicator was able to produce, a clear determination as to whether or not replacing a newspaper's content is possible will be made.

Coding the content based on originality, locality, and how well it serves the community's critical information needs will also help to determine the quality of the local news that is produced. 
Original reporting is reporting done by reporters who work for the outlet, not any syndicated stories such as stories from the Associated Press. Local reporting is reporting on the specific community which the outlet serves. Critical information needs are the information a news outlet can provide to a community that best serves that community.

At the time of its closure The Vindicator employed 19 reporters producing news for the Youngstown community. Original reporting is an important aspect of a local newspaper's content (Napoli et al, 2017) and so original reporting needs to be a main factor of any outlet that tries to replace a local paper.

$R Q 1$ : How will the examined outlets' amount of original reporting post-Vindicator compare to The Vindicator's amount of original reporting?

As previously stated, The Vindicator was the only newspaper that primarily carried coverage of Mahoning, Trumbull, and Columbiana counties. In order to adequately replace The Vindicator's coverage, outlets like The Tribune Chronicle will need to add coverage of these areas that they had not covered in the past.

$R Q 2$ : How will the examined outlets' number of stories covering the Mahoning, Trumbull, and Columbiana counties compare to The Vindicator's amount of coverage of those areas?

As seen in previous research (Barnett and Townend, 2015; Smith, 2008; Shaker, 2014), the quantity of content produced is not the aspect of The Vindicator's coverage that these outlets will 
need to replace. The quality of a newspaper's reporting and the connection to its community will need to be a part of any outlet's coverage if they hope to effectively replace The Vindicator.

$R Q 3:$ Will the examined outlets' coverage fulfill as many of the community's critical information needs as The Vindicator's coverage did?

\section{Methodology}

This study is a content analysis of the five major local media outlets in the Youngstown area since the closure of The Vindicator. Content from these outlets has been coded for originality, locality and fulfilment of the community's critical information needs. Those results have been compared with content collected from the last six months of The Vindicator's operation that was coded for the same measurements. The comparison of the results shows how the local media ecology has changed since The Vindicator's closure.

\section{The Framework for Measurement}

Napoli et al (2017) measured the effectiveness of local media by examining certain characteristics of local media outlets and analyzing the content these outlets produce. They developed a framework that is general and was intended to facilitate the examination of local media in large groups of communities all at once for the purpose of comparison of local media ecologies between communities. The framework involves three metrics on which local media ecologies can be measured: journalistic infrastructure, output, performance. 
Napoli et al (2017) defined journalistic infrastructure as the number, size and characteristics of news outlets within a community. For output, Napoli et al measured the amount of content produced by the aggregate of the infrastructure for each community. They determined that, "a reasonable indicator of the health of a local journalism ecosystem is the amount of journalism that is produced for and within the community (381)". They conducted a one-week content analysis of each outlet's website homepage and social media profiles, counting and coding each story each day. Performance is the most difficult dimension to evaluate. Napoli et al measured it with three variables; amount of original content, how locally focused the news is, and how well the news supplies the community's critical information needs (CIN). Originality was coded as the content either being originally produced or not and local focus was coded as and either being locally focused or not. The CINs used come from Friedland et al (2012), who developed eight areas of information critical to local communities:

1. Emergencies and Public Safety

2. Health

3. Education

4. Transportation Systems

5. Environment and Planning

6. Economic Development

7. Civic Information

8. Political Life 
CINs are meant to be universal categories for which to judge journalistic performance, so a story need only fulfil a single one to qualify (Napoli et al, 2017). If a story fulfills a CIN, that means it holds value to the outlet's community. By measuring how many CIN fulfilling stories an outlet produces, one can start to make a determination of how well that outlet serves its community's needs.

\section{Adapting the Framework}

In order to measure how the information needs of the Youngstown and Mahoning Valley community are being met, an understanding of said needs must first be established. The framework developed by Napoli et al (2017) is general and was meant to facilitate the examination of local media in large groups of communities all at once. Focusing on just one local media ecology in one community will require refinement of this framework.

Mahone et al (2019) identified the four major local media outlet types: radio stations, television stations, newspapers, and online-only outlets. These were the types of outlets considered for this study. Outlets that will be included are; WKBN (TV), WFMJ (TV), The Business Journal (newspaper), The Tribune Chronicle (newspaper), and Mahoning Matters (online-only). These five outlets are members of the Youngstown Press Club and were represented on the Who's Who in Local News panel held on October 7, 2019 at the Newport Library in Youngstown.

A content analysis of local media outlets in the area post-Vindicaor was conducted. The outlets were content analyzed on the four different metrics used by Napoli et al (2017). Those metrics are the amount of content produced, whether or not that content is original, whether or not that 
content is locally-based, and the extent to which that content fulfils the community's critical information needs (CIN) identified in Friedland et al (2012). The process coders used when coding for these metrics can be found in Appendix A.

The sampling period lasted for one week from January 5 through January 10, 2020 and included all content featured on the outlets' home webpages. Six days was chosen as acceptable because Wang (2006) found that a sample size of six days was enough to represent six months of news content. The data gathered were analyzed to determine the amount of content produced by each outlet and if that content was originally reported, locally focused and if it fulfilled a CIN.

\section{Comparing the Results}

The results from the content analysis of existing outlets was compared to a content analysis of The Vindicator prior to its closing. A constructed week of The Vindicator from its last six months of operation was content analyzed using the same criteria. A constructed week of The Vindicator was made by choosing a date at random for each day of the week of The Vindicator's last six months and examining the paper on that date.

The constructed week is made up of the following dates:

Monday: August 5, 2019

Tuesday: May 14, 2019

Wednesday: May 29, 2019

Thursday: May 2, 2019

Friday: July 19, 2019 
Saturday: August 24, 2019

Connolly-Ahern et al (2009) concluded that a sample size of two weeks is representative of one full year of a traditional newspaper. Since this study will only focus on The Vindicator's final six months, only six days were constructed. An abbreviated constructed week was used because it provides better estimates and representation over purely random sampling (Riffe et al, 1993). A random sampling of days could oversample weekends or weekdays, which could skew results.

\section{Sample}

Each day of the sample period each of the five current publications' website homepages were examined starting at 4 p.m. EST. Stories to be analyzed were chosen from the websites' showcase sections. Each of the five publications' website homepages, except for mahoningmatters.com, feature a slideshow of featured stories. Additional stories to be analyzed were also chosen from the websites' "Latest News" (Business Journal, Tribune Chronicle), "More News" (WFMJ) or "Top News" (WKBN) sections

The sample from the last six month of The Vindicator was collected using two websites, archive.org and vindyarchives.com. vindyarchives.com is a collection of all the stories published by The Vindicator online, searchable by date. This allows access to content from each of the days selected in the constructed week. Archive.org allows users to view webpages on specific dates. This allowed for examination of The Vindicator's website on the selected dates. Using archive.org the researcher was able to identify which stories were featured on The Vindicator's webpage on each date and then the researcher was able to examine those stories using 
vindyarhives.com. Like the other publications' webpages, The Vindicator's website homepage had a slideshow of feature stories and a "Today's Top Headlines" section that stories were selected from.

\section{Reliability}

The researcher coded 355 articles collected from the six publications; 105 from The Vindicator and 250 from the post-Vindicator publications. To assess intercoder reliability, a second coder coded 24 non-Vindicator articles $(9.6 \%)$ collected on the first day of the sampling period. Reliability was assessed using the Cohen's kappa coefficient, which is a statistic used to determine interrater reliability for categorical items.

Cohen's kappa was calculated for each of the categories explained in Appendix A. According to McHugh (2012) a kappa of 0.61-0.8 is substantial agreement and 0.8-1.0 is almost perfect. Publication, originality and Vindicator coverage area all had perfect values of 1.0. Locality had a 0.705 and critical information needs had 0.685 . Each of these numbers fall within acceptable range for reliability. All five categories therefore fall within the top two ranges.

The chi-square statistic was also calculated on results when its assumptions could be met. The chi-square test is used for counted data (such as categories) rather than measured data. The test determines the goodness of fit between variables and its results can suggest if two categorical variables are related.

\section{Results}


A simple count of the total number of articles examined from each outlet shows that The Vindicator featured the highest number of stories on its website homepage (see Table 1). In order following The Vindicator the most stories examined were produced by WKBN, WFMJ, the Tribune Chronicle, Mahoning Matters and the Business Journal.

TABLE 1 Stories Analyzed for Each Publication

\begin{tabular}{|l|l|}
\hline Publication & Number of Articles Examined \\
\hline Vindicator & 105 \\
\hline WKBN & 72 \\
\hline WFMJ & 63 \\
\hline Tribune Chronicle & 41 \\
\hline Mahoning Matters & 39 \\
\hline Business Journal & 35 \\
\hline
\end{tabular}

\section{Research Question 1}

RQ1 asked how the amount of original reporting produced by the outlets post-Vindicator would compare to the amount of original reporting produced by The Vindicator. By count, The Vindicator had the lowest rate of original reporting, 58 percent (see Table 2). Every publication post-Vindicator and the post-Vindicator total had an original reporting rate at least 13 points 
higher than The Vindicator's. Mahoning Matters ( 87 percent) and WKBN (82 percent) were the only publications with original reporting rates higher than 80 percent. The Vindicator (58 percent) was the only publication with an original reporting rate below 70 percent, however, it still had the highest number of original stories.

TABLE 2 Original Reporting by Publication

\begin{tabular}{|l|l|l|}
\hline Publication & Original Reporting & Non Original Reporting \\
\hline Vindicator & $\mathbf{6 1}(\mathbf{5 8 \%})$ & $\mathbf{4 4}(\mathbf{4 2 \%})$ \\
\hline Post-Vindicator Total & $\mathbf{1 9 5}(\mathbf{7 8 \%})$ & $\mathbf{5 5}(\mathbf{2 2 \%})$ \\
\hline Mahoning Matters & $34(87 \%)$ & $5(13 \%)$ \\
\hline WKBN & $59(82 \%)$ & $13(18 \%)$ \\
\hline Tribune Chronicle & $31(76 \%)$ & $10(24 \%)$ \\
\hline Business Journal & $26(74 \%)$ & $9(26 \%)$ \\
\hline WFMJ & $45(71 \%)$ & $18(29 \%)$ \\
\hline
\end{tabular}

A chi-square test comparing original reporting Vindicator and post-Vindicator content reporting suggests that there is a statistically significant difference of original reporting based on publication, $x^{2}(1, N=355)=13.59, \mathrm{p}<.05$. 
RQ2 asked how the amount of local coverage would compare between The Vindicator and the post-Vindicator outlets. By count, The Vindicator had the lowest percent of stories with a local focus, 61 per cent (see Table 3). The Business Journal (69 percent) was the only other outlet with a percent of stories with a local focus under 70 per cent. WKBN (81 percent) and the Tribune Chronicle (76 percent) had the highest rates of stories with a local focus. The post-Vindicator total's percent of stories with a local focus ( 75 percent) was 14 points higher than The Vindicator's (61 percent).

TABLE 3 Local Focus by Publication

\begin{tabular}{|l|l|l|}
\hline Publication & Local Focus & Non Local Focus \\
\hline Vindicator & $\mathbf{6 4}(\mathbf{6 1 \%})$ & $\mathbf{4 1}(\mathbf{3 9 \%})$ \\
\hline Post-Vindicator Total & $\mathbf{1 8 7}(\mathbf{7 5 \%})$ & $\mathbf{6 3}(\mathbf{2 5 \%})$ \\
\hline WKBN & $58(81 \%)$ & $14(19 \%)$ \\
\hline Tribune Chronicle & $31(76 \%)$ & $10(24 \%)$ \\
\hline Mahoning Matters & $29(74 \%)$ & $10(26 \%)$ \\
\hline WFMJ & $45(71 \%)$ & $18(29 \%)$ \\
\hline Business Journal & $24(69 \%)$ & $11(31 \%)$ \\
\hline
\end{tabular}


A chi-square test comparing local focus in Vindicator and post-Vindicator content suggests that there is a statistically significant difference of local focus based on publication , $x^{2}(1, N=355)$ $=6.19, \mathrm{p}<.05$.

The communities that relied the most on The Vindicator's coverage, according to former Vindicator editor Todd Franko, were Boardman, Austintown, Poland and Canfield. By count, The Vindicator provided more coverage to each of those communities than any other single publication. The Vindicator had 18 total stories about those communities, and the five postVindicator outlets combined had 25 total stories (see Table 4). Two outlets (Tribune Chronicle, WFMJ) provided no coverage of Austintown, and three publications (Business Journal, Mahoning Matters, WFMJ) provided no coverage of Poland. Every outlet covered Boardman and Canfield at least once. 
TABLE 4 Local Focus of Vindicator Coverage Area by Publication

\begin{tabular}{|l|l|l|l|l|}
\hline Publication & Boardman & Austintown & Poland & Canfield \\
\hline Vindicator & $\mathbf{2}$ & $\mathbf{5}$ & $\mathbf{2}$ & $\mathbf{9}$ \\
\hline Post-Vindicator & $\mathbf{9}$ & $\mathbf{5}$ & $\mathbf{3}$ & $\mathbf{8}$ \\
\hline $\begin{array}{l}\text { Tribune } \\
\text { Chronicle }\end{array}$ & 2 & 0 & 2 & 1 \\
\hline Business Journal & 1 & & 0 & 1 \\
\hline Mahoning & 1 & 2 & 0 & 3 \\
Matters & & 1 & 0 & 1 \\
\hline WFMJ & 2 & 0 & 1 & 2 \\
\hline WKBN & 3 & 2 & & 1 \\
\hline
\end{tabular}

A chi-square goodness of fit test could not be conducted with this data as too many have values of less than five.

\section{Research Question 3}

RQ3 asked how the community's critical information needs (CIN) were fulfilled post-Vindicator compared to how The Vindicator fulfilled them. By count, The Vindicator had the highest percentage of stories that did not fulfill a CIN at 20 percent (see Table 5). The Tribune Chronicle's rates most closely reflected The Vindicator's, with the largest difference only being 
eight points in emergencies and public safety. The Business Journal had the highest percentage of economic development stories (22 percent), Mahoning Matters had the highest percent of civic information stories (33 percent) and the two television stations, WFMJ and WKBN had the highest rates of emergencies and public safety stories (44 and 46 percent). 
TABLE 5 Critical Information Needs by Publication

\begin{tabular}{|c|c|c|c|c|c|c|c|c|c|}
\hline Pub & EPS & HEA & EDU & TRAN & ENV & ECON & CIV & POL & None \\
\hline Vin & $\begin{array}{l}25 \\
(24 \%)\end{array}$ & $2(2 \%)$ & $5(5 \%)$ & $2(2 \%)$ & $3(3 \%)$ & $8(8 \%)$ & $\begin{array}{l}19 \\
(18 \%)\end{array}$ & $\begin{array}{l}20 \\
(19 \%)\end{array}$ & $\begin{array}{l}21 \\
(20 \%)\end{array}$ \\
\hline $\begin{array}{l}\text { Post- } \\
\text { Vin }\end{array}$ & $\begin{array}{l}76 \\
(30 \%)\end{array}$ & $\begin{array}{l}18 \\
(7 \%)\end{array}$ & $\begin{array}{l}17 \\
(7 \%)\end{array}$ & $8(8 \%)$ & $3(1 \%)$ & $\begin{array}{l}38 \\
(15 \%)\end{array}$ & $\begin{array}{l}49 \\
(20 \%)\end{array}$ & $\begin{array}{l}29 \\
(12 \%)\end{array}$ & $\begin{array}{l}12 \\
(5 \%)\end{array}$ \\
\hline$T C$ & $\begin{array}{l}13 \\
(32 \%)\end{array}$ & $2(5 \%)$ & $\begin{array}{l}4 \\
(10 \%)\end{array}$ & $1(2 \%)$ & $1(2 \%)$ & $3(7 \%)$ & $\begin{array}{l}8 \\
(20 \%)\end{array}$ & $\begin{array}{l}8 \\
(20 \%)\end{array}$ & $1(2 \%)$ \\
\hline$B J$ & $0(0 \%)$ & $3(9 \%)$ & $2(6 \%)$ & $1(3 \%)$ & $1(3 \%)$ & $\begin{array}{l}15 \\
(43 \%)\end{array}$ & $\begin{array}{l}8 \\
(22 \%)\end{array}$ & $2(6 \%)$ & $3(9 \%)$ \\
\hline$M M$ & $2(5 \%)$ & $\begin{array}{l}6 \\
(15 \%)\end{array}$ & $\begin{array}{l}5 \\
(13 \%)\end{array}$ & $0(0 \%)$ & $1(3 \%)$ & $\begin{array}{l}6 \\
(15 \%)\end{array}$ & $\begin{array}{l}12 \\
(30 \%)\end{array}$ & $\begin{array}{l}6 \\
(15 \%)\end{array}$ & $1(3 \%)$ \\
\hline$W F M J$ & $\begin{array}{l}28 \\
(44 \%)\end{array}$ & $3(5 \%)$ & $4(6 \%)$ & $4(6 \%)$ & $0(0 \%)$ & $\begin{array}{l}6 \\
(10 \%)\end{array}$ & $\begin{array}{l}8 \\
(13 \%)\end{array}$ & $\begin{array}{l}7 \\
(11 \%)\end{array}$ & $3(5 \%)$ \\
\hline$W K B N$ & $\begin{array}{l}33 \\
(46 \%)\end{array}$ & $4(6 \%)$ & $2(3 \%)$ & $2(3 \%)$ & $0(0 \%)$ & $\begin{array}{l}8 \\
(11 \%)\end{array}$ & $\begin{array}{l}13 \\
(18 \%)\end{array}$ & $6(8 \%)$ & $4(6 \%)$ \\
\hline
\end{tabular}

A chi-square goodness of fit test could not be conducted with this data as too many have values of less than five. 
In just fulfilling a CIN, every outlet outperformed The Vindicator in terms of percent, 80 percent (see Table 6). However, The Vindicator produced more stories that fulfilled a CIN, 84, than any other single outlet on its own.

TABLE 6 Fulfilled Critical Information Needs by Publication

\begin{tabular}{|l|l|l|}
\hline Publication & Fulfilled CIN & Did Not Fulfill CIN \\
\hline Vindicator & $\mathbf{8 4}(\mathbf{8 0} \%)$ & $\mathbf{2 1}(\mathbf{2 0} \%)$ \\
\hline Post-Vindicator & $\mathbf{2 3 8}(\mathbf{9 5 \%})$ & $\mathbf{1 2}(\mathbf{5 \%})$ \\
\hline Tribune Chronicle & $40(98 \%)$ & $1(2 \%)$ \\
\hline Mahoning Matters & $38(97 \%)$ & $1(3 \%)$ \\
\hline WFMJ & $60(95 \%)$ & $3(5 \%)$ \\
\hline WKBN & $68(94 \%)$ & $4(6 \%)$ \\
\hline Business Journal & $32(91 \%)$ & $3(9 \%)$ \\
\hline
\end{tabular}

\section{Discussion}

It is apparent that The Vindicator was a publication unlike any of the ones remaining in Youngstown. The coverage it provided was unique in both its volume and makeup. The Vindicator produced the most originally reported and locally focused content as well as the most not originally reported and not locally focused content (see Tables 2 and 3). 
The other five outlets all produced content that was originally reported and locally focused at much higher rates than The Vindicator, but at lower volume (See Table 1). As a newspaper, The Vindicator provided readers with both local and non-local news content, giving readers, presumably, a full range of news every day. While the other outlets may be able to make up for the loss in local coverage, none of them produced nearly as much non-local content as The Vindicator. This may be moot, however, as statewide and national stories are readily accessible from larger outlets, usually online.

The results of RQ1 and RQ2 were more closely linked than originally anticipated. Nearly all originally reported stories were locally focused, while many not originally reported stories did not have a local focus. Of The Vindicator's 61 stories that were originally reported, 60 (98 percent) had a local focus, with only one not having a local focus. Of The Vindicator's 44 not originally reported stories, 40 of them (91 percent) were not locally focused and only four did have a local focus.

The hyperlocal publication in this study, Mahoning Matters, acted as Metzgar et al (2011) described, filling in gaps in coverage. Mahoning Matters produced the most stories about health (six stories) and education (five stories), even more than The Vindicator (see Table 5). Other than the Business Journal (zero stories), Mahoning Matters had the lowest number of stories about emergencies and public safety (two stories). One can assume that Mahoning Matters did not have a lot of coverage on emergencies and public safety because outlets such as WFMJ (28 stories) and WKBN (33 stories) already extensively cover the topic. This furthers the point that 
hyperlocal publications work to fill in the gaps in coverage, not double down on what other outlets are already reporting on.

The two daily newspapers, The Vindicator and the Tribune Chronicle, had the highest concentration of stories in emergencies and public services ( 24 and 32 percent), civic information (18 and 20 percent) and political life (19 and 20 percent). These three CINs reflect what one could reasonably expect a daily newspaper's coverage to focus on: hard, impactful news, community news and information, and local politics. The Business Journal, a niche business publication, had its highest concentrations in economic development (43 percent) and civic information (22 percent). Mahoning Matters, had its highest concentration in civic information (30 percent), but economic development (15 percent), political life (15 percent), health (15 percent) and education (13 percent) were very close together. The two television stations, WFMJ and WKBN, had the highest concentration of stories in emergencies and public services (44 and 46 percent) and civic information (13 and 18 percent). As Cooper (2000) found, broadcast media tends towards stories that include tragedy or injury, so-called fear-based media.

Shaker (2014), Jeffres et al (2002), Watson and Cavanah (2015), Hoffman and Eveland (2010) and Smith (2008) all claimed that a daily newspaper provides intrinsic value to its community beyond just the news it produces. Community identification, engagement, attachment, integration, and involvement are all aspects that these researchers claim are heightened by a community's local newspaper. These intangible qualities of a local newspaper will be the most difficult aspects of newspaper closure to quantify and examine and may very well be what communities miss the most. The Tribune Chronicle moving into the area may help in these areas, 
however Smethers et al (2007) found that a majority of citizens did not feel an area newspaper adequately replaced a local newspaper. An area newspaper being a publication that is produced from outside the community, unlike a local newspaper that is produced in its community. Shaker (2014) found that even large cities like Denver and Seattle, both larger and with more robust media ecologies than Youngstown, still felt the adverse effects of losing their local newspapers. In Denver, the city's civic engagement went down, with citizen joining less community organizations and participating less in local government. As seen in the outlets' CIN number, two of the CINs that The Vindicator covered the most were civic information and political life. It may be possible for local media ecologies to replace the content and coverage of local newspapers when they close, but it could be impossible, or at least unquantifiable, to replace the intangible aspects of a community's local newspaper.

As expected, this study can make no definite determination on whether or not a daily newspaper's content can be wholly replaced upon its closure. That was not the main goal of this study, the main goal was to try and identify what changes would happen to a local media ecology upon a newspaper's closure. In this pursuit, this study has made some determinations. First and foremost, no one outlet will be able to fully replace The Vindicator, but the aggregate of outlets in the area may be able to. This is, however, one of the things that will be lost with the closure of the community's local paper. Whereas before readers could just read content from The Vindicator, those same readers would now need to consume content from multiple outlets to match that.

\section{Limitations}


The biggest limitation of this research was limited time, manpower and resources. With just one researcher and coder, sampling periods had to be limited to six days to avoid the risk of having an unmanageable data set. A longer sampling period would provide better defense against any outliers in coverage that could skew the sample such as a big event or disaster that might dominate a publication's coverage for several days. A longer sampling period would provide a more complete representation of an outlet.

More than just the content feature on the publications' website homepages would also be ideal to analyze. With more coders, one could analyze every piece of content produced by a publication over the sampling period, not just a select amount. Outlets could also be analyzed in their intended medium. Television stations such as WFMJ and WKBN could have broadcasts content analyzed while print publications like The Vindicator, the Tribune Chronicle and the Business Journal could have printed publications analyzed, while digital-only publications such as Mahoning Matters could just have the website examined.

Publications would also ideally not be sampled congruently. Because the five current publications sampled in this research cover the same general area, the publications' coverage overlapped the same topics and events multiple times. Sampling each publication separately could help to ensure that the entire data set is not skewed by overrepresentation of one event or topic that just happened to be covered by each outlet.

Another flaw in this research is that The Vindicator was the only outlet sampled from the past. The five current outlets were sampled together to represent the current media landscape of the 
area, but just The Vindicator was sampled to represent the former media landscape. The Business Journal, WFMJ and WKBN were all active alongside The Vindicator in the past, but limits in technology and the outlets' websites prevented them from being included in the sample of the past with The Vindicator. This left the representation of Youngstown's previous media landscape incomplete.

For intercoder reliability, the discrepancies in coding for locality may have been caused by the second coder being unfamiliar with the area in question. Future codebooks should provide a comprehensive list of which areas should be considered local. The discrepancies in identifying critical information needs may have been because several articles could have acceptably been identified as fulfilling multiple CINs. For the broader question on if a story fulfils even a single CIN, however, there were only two instances of discrepancy between the coders.

\section{Future Research}

Continued research on this topic would be valuable as a way to further contextualize the effects of newspaper closure. A local newspaper closure in one community may, or may not, have different effects than a different newspaper closure in a different community. There are unique aspects to Youngstown, Ohio that may not make it representative of other newspapers in other communities. The largest is that Youngstown has several other local media outlets. Smaller communities may only have a local newspaper and nothing else, not television stations, hyperlocals or niche publications like Youngstown does. Further research of other newspaper closures in other communities would help to determine which effects are universal and which effects are specific to each community, or type of community. 
Further research could also better contextualize the local media ecology prior to the newspaper's closure. A researcher could begin collecting data on a community's media landscape as soon as a newspaper announces its closure, not months afterward such as this study. Beginning examination immediately upon announcement would give researchers the opportunity to track the community's media ecology the entire time through the newspaper's closure. Possibility for weeks or months while the newspaper is losing and then weeks or months following its closure and examine specifically how the media landscape changes at different points in the transition. 


\section{References}

Barnett, S. \& Townend, J. (2015). Plurality, Policy and the Local: Can Hyperlocals Fill the Gap? Journalism Practice, 9(3), 332-349. https://doi.org/10.1080/17512786.2014.943930

Benton, J. (2019, August 19). So Youngstown Will Have a Daily Named The Vindicator After All. But It's a Brand Surviving, Not a Newspaper. Retrieved from https://www.niemanlab.org/2019/08/so-youngstown-will-have-a-daily-named-the-vindicatorafter-all-but-its-a-brand-surviving-not-a-newspaper/

Boney, S. (2019, September 3). WKBN Welcomes Seasoned Vindicator Reporter Joe Gorman to Staff. Retrieved from https://www.wkbn.com/news/local-news/wkbn-welcomes-seasonedvindicator-reporter-joe-gorman-to-staff/

Connolly-Ahern, C., Ahern, L., \& Bortree, S. (2009). The Effectiveness of Stratifies Constructed Week Sampling for Content Analysis of Electronic News Source Archives. Journalism \& Mass Communication Quarterly, 86(4), 862-883.

Cooper, C. P. \& Roter, D. L. (2000). "If it Bleeds it Leads"? Attributes of TV Health News Stories That Drive Viewer Attention. Public Health Rep., 115(4), 331-338. https://dx.doi.org/10.1093\%2Fphr\%2F115.4.331

Forman, C. (2019, March 26). McClatchy and Google Partner on an Experimental Lab for Local News. Retrieved from https://www.blog.google/outreach-initiatives/google-newsinitiative/mcclatchy-and-google-partner-experimental-lab-local-news/

Friedland, L., Napoli, P., Ognyanova, K., Weil, C., \& Wilson III, E. (2012, July 16). Review of the Literature Regarding Critical Information Needs of the American Public. http://transition.fcc.gov/bureaus/ocbo/Final_Literature_Review.pdf

Gabbatt, A. (2019, August 21). Ohio Newspaper that Battle Injustice for 150 Years to Shut Down: 'Scary for Democracy'. Retrieved from https://www.theguardian.com/usnews/2019/aug/21/the-vindicator-ohio-newspaper-shut-down

Ha, L. \& Zhang, X. (2017). Are Online Versions of Newspapers Inferior Goods or Public Goods? Empirical Evidence from U.S. National and Local Markets. China Media Research, 13(1), 3-19. 
Hoffman, L. \& Eveland, W. (2010). Assessing Causality in the Relationship Between Community Attachment and Local News Media Use. Mass Communication and Society, 13, 174-195. https://doi.org/10.1080/15205430903012144

Jeffres, L., Atkin, D., \& Neuendorf, K. (2002). A Model Linking Community Activity and Communication With Political Attitudes and Involvement in Neighborhoods. Political Communication, 19, 387-421. https://doi.org/10.1080/01957470290055574

Jenkins, M. (2019a, July 18). The Compass Experiment is on its way to Youngstown. Retrieved from https://medium.com/the-compass-experiment/the-compass-experiment-is-on-its-way-toyoungstown-69791d965f8

Jenkins, M. (2019b, September 5). Introducing Mahoning Matters and our locals news team in Youngstown. Retrieved from https://medium.com/the-compass-experiment/introducingmahoning-matters-and-our-local-news-team-in-youngstown-c0bf9df0b2b2

Mahone, J., Wang, Q., Napoli, P., Weber, M., \& McCollough, K. (2019). Who's Producing Local Journalism? Assessing Journalistic Output Across Different Outlet Types. News Measures Research Project, August 2019.

McHugh, M. (2012). Interrater Reliability: The Kappa Statistic. Biochem Med (Zagreb), 22(3), 276-282.

Metzgar, E., Kurpius, D., \& Rowley, K. (2011). Defining Hyperlocal Media: Proposing a Framework for Discussion. New Media \& Society, 13(5), 772-787.

https://doi.org/10.1177/1461444810385095

Napoli, P., Stonbely, S., McCollough, K., \& Renninger, B. (2017). Local Journalism and the Information Needs of Local Communities: Toward a Scalable Assessment Approach. Journalism Practice, 11(4), 373-395. https://doi.org/10.1080/17512786.2016.1146625

Nelson, G. (2019, June 28). In Depth: Vindicator to Cease Production Aug. 31. Retrieved from https://businessjournaldaily.com/vindicator-to-cease-publication-in-august/

Nygren, G., Lecknew, S., \& Tenor, C. (2017). Hyperlocals and Legacy Media: Media Ecologies in Transition. Nordicon Review, 39(1), 33-49. https://doi.org/10.1515/nor-2017-0419

Riffe, D., Aust, C., \& Lacy, S. (1993). The Effectiveness of Random, Consecutive Day and Constructed Week Sampling in Newspaper Content Analysis. Journalism Quarterly, 70(1), 133139. 
Shaker, L. (2014). Dead Newspapers and Citizens' Civic Engagement. Political Communication, 31, 131-148. https://doi.org/10.1080/10584609.2012.762817

Siles, I. \& Boczkowski, P. (2012). Making Sense of the Newspaper Crisis: A Critical Assessment of Existing Research and an Agenda for Future Work. New Media \& Society, 14(8), 1375-1394. https://doi.org/10.1177/1461444812455148

Smethers, S., Bressers, B., Willard, A., Harvey, L., \& Freeland, G. (2007). Kansas Readers Feel Loss When Town's Paper Closes. Newspaper Research Journal, 28(4), 6-21.

Smith, R. (2008). How Two Veteran Journalists in Opposing Media Encouraged a Sense of Community in a Georgia Town. Journalism History, 34(2), 107-116.

U.S. Census Bureau. (2018). Quick Facts Youngstown City, Ohio. Retrieved from https://www.census.gov/quickfacts/youngstowncityohio

Wadbring, I. \& Bergstrom, A. (2017). A Print Crisis or a Local Crisis? Local News USe Over Three Decades. Journalism Studies, 19(2), 175-190. https://doi.org/10.1080/1461670X.2015.1042988

Wang, X. (2006). Exploring Sample Sizes for Content Analysis of Online News Sites. Communication Theory \& Methodology Division, AEJMC.

Watson, B. \& Cavanah, S. (2015). Community Information Needs: A Theory and Methodological Framework. Mass Communication and Society, 18, 651-673. https://doi.org/10.1080/15205436.2015.1059948 


\section{Appendix A: Codebook}

The population of analysis consists of all of the stories in the "top news" sections on the five news outlets' websites. It also includes stories in the first section of issues of The Vindicator. There are two components of the sample, a constructed week of The Vindicator's final six months of operation and stories produced by the five current outlets during a one-week period.

The unit of analysis is every individual story published by the observed outlets during the observation period.

Each unit will be coded for publication information: outlet of publication (The Vindicator, The Business Journal, Mahoning Matters, WFMJ, WKBN, The Tribune Chronicle) and date of publication (day, date and year).

Beyond publication, each unit will be coded for three variables: original reporting, locality and satisfaction of critical information needs. Original reporting will be coded as whether a story was first reported by the outlet. Locality will be coded as whether the is about the Mahoning Valley area; it will also note which specific community in the area it covers. Critical information needs will be coded as whether one or more of those needs are fulfilled.

1. Identifying Original Reporting. The presence of a reporter's byline is the first and best indicator of original reporting. If that reporter works for the outlet, it is highly likely that the story is original. The story's dateline (if present) is also a good indicator of originality. A story with a local dateline would be highly likely to be original. The 
presence of Associated Press (AP), or other such national outlets, either in the byline or dateline of the story is a good indicator that the story is not original. Such stories could also include a disclaimer at the bottom of the page. An example of such a disclaimer is “Copyright 2019 The Associated Press. All rights reserved. This material may not be published, broadcast, rewritten or redistributed." If no such indicators are present, or the originality of the story is difficult to determine, the content of the story can also be used as a determinant. If the story is about a local event or issue, it is more likely to be original reporting. If the content of the story is on a national scale, it is more likely to not be original reporting.

2. Determining Locality. The best indicator of locality is the story's dateline, if present. The dateline could give all the information needed to code the locality. For example, a dateline that is "LORDSTOWN, Ohio --" or "WARREN TWP., Ohio --" gives all the information needed to code the story as either Lordstown or Warren. In the absence of a dateline, the locality of the story could be found in the story's headline or lede. For example, the headline "Leetonia Police offer solution to 'porch piracy"' reveals the story is about Leetonia, which is in Columbiana County, Ohio. The lede "A portion of North River Road NW in Warren Township has reopened, and a suspect is in custody following a manhunt." shows the story is about Warren, which is in Trumbull County, Ohio. If the location is not revealed in the story's headline or lede and there is no dateline, it may be required to read the story in its entirety to determine its locality. The stories that are determined to be local will then be coded one level further for the Vincidator's main coverage areas: Boardman, Austintown, Poland and Canfield. 
3. Fulfilling Critical Information Needs. There are eight CIN categories that a story can fulfill to be coded as satisfying a critical information need. A story need only fit into one of the categories to be coded as satisfying the community's CIN. Stories will need to be read in full to accurately determine if they fulfill a CIN. Friedland et al (2012) outline aspects of each category that will be used as a basis for this analysis. Stories should only be coded for the one category that best fits. The eight CIN categories and their aspects as defined by Friedland et al (2012) are as follows:

1. Emergencies and Public Safety - Emphasizes dangerous weather, environmental and other biohazardous outbreaks, terrorism, amber alerts.

2. Health - Emphasizes the availability, quality, and cost of local health care, availability of local health information, programs, and services, wellness care, local clinics, hospitals, the spread of disease, vaccinations, local health campaigns, interventions.

3. Education - Emphasizes the local educational system, decision-making, resource allocation, administration, quality of schools, performance assessments, enrichment, tutoring, after-school care and programs, school alternatives, language courses, job training, GED programs, local opportunities for higher education.

4. Transportation Systems - Emphasizes essential transportation services, mass transit at the neighborhood, city, and regional levels, traffic and road conditions related to weather, closings.

5. Environment and Planning - Emphasizes planning issues that affect the quality of lives in neighborhoods, cities, and metropolitan regions, the quality of regional 
water and air, alerts of hazards, sustainability, toxic hazards, watersheds, habitats, opportunities for recreation.

6. Economic Development - Emphasizes employment information and opportunities, job training and retraining, apprenticeship, reskilling and advancement, small business opportunities, startup assistance, capital resources, major economic initiatives.

7. Civic Information - Emphasizes major civic institutions, nonprofit organizations and associations, services, accessibility, opportunities, libraries, community-based information services, cultural and arts information, recreational opportunities, community-based social services and programs, religious institutions.

8. Political Life - Emphasizes local, regional, and county candidates at all units of governance, elected and voluntary neighborhood councils, school boards, city council, county elections, public meetings and issues, information on where and how to register to vote, state-level issues, local policy formation and decisions.

\section{Other}


Codebook:

I. Coding for: Publication

Coding unit: Article

Categories:

VIN: Vindicator

TBJ: The Business Journal

TC: Tribune Chronicle

MM: Mahoning Matters

WFMJ: WFMJ

WKBN: WKBN

II. Coding for: Originality

Coding unit: Article

Categories:

OR: Original Reporting

NOR: Not Original Reporting

III. Coding for: Locality

Coding for: Article

Coding unit: Original reporting

Categories:

LF: Local Focus

NLF: Not Local Focus 
Coding for: Vindicator Coverage Area

Coding Unit: Local Focus

Categories:

BDM: Boardman
AUS: Austintown
POL: Poland
CAN: Canfield

IV. Coding for: Critical Information Needs (CIN)

Coding Unit: Article

Categories:

EPS: Emergencies and Public Safety

HEA: Health

EDU: Education

TRAN: Transportation Systems

ENV: Environment and Planning

ECON: Economic Development

CIV: Civic Information

POL: Political Life 